\title{
PEMBABATAN HUTAN, PEMBUNUHAN HEWAN, SISTEM PEMAKAMAN DI INDONESIA SERTA PEMBANGUNAN BANDARA DI KULON PROGO JIKA DILIHAT DARI KACAMATA DIMENSI DASAR MANUSIA
}

\author{
Patrik Krisna Murti \\ Prodi Teknik Industri Universitas Katolik Widya Mandala Madiun \\ Patrikkrisna1@gmail.com
}

\begin{abstract}
ABSTRAK
Manusia merupakan makluk yang memiliki akal budi diantara makluk ciptaan Tuhan yang lainnya, namun terkadang manusia juga kehilangan akal budinya untuk peduli dengan sesama antar ciptaan Tuhan terutama menjaga lingkungan yang ada di bumi dan negara banyak hutan dan hewan yang dibunuh hal itu dapat dilihat bahwa manusia kurang peduli dengan dirinya dan sesama jika dilihat dari sudut pandang dimensi dasar manusia "aku dan yang lain", serta jika kita melihat sistem pemakaman di Indonesia yang berbeda - beda yang dipengaruhi oleh beberapa faktor diantara mampu dilihat dari segi sudut pandang filsof bahwa manusia berasal dari tanah dan kembali lagi ke tanah. Serta jika dikaitkan dengan kasus pembangunan bandara di kulon progo jika ditinjau dari dimensi dasar manusia tentang sosialitas yang menjadi cara menunjukkan kehidupan bersama dan pengaruhnya pembangunan itu jika dilihat dari dua posisi ekstrim dalam sosialitas yaitu kolektivisme bahwa kepentingan bersama lebih penting dari kepentingan pribadi.

Kata kunci : aku dan yang lain, sosialitas, manusia berasal dari tanah kembali ke tanah
\end{abstract}

\section{A. PERMASALAHAN ATAU FENOMENA YANG DIANGKAT}

Kondisi yang diangkat antara lain banyaknya penebangan dan pembabatan hutan liar serta pembunuhan hewan yang marak terjadi di Indonesia serta sistem pemakaman yang dipengaruhi oleh adat istiadat yang berada di Indonesia dan permasalahan pembangunan bandara di kulon progo karena banyaknya masyrakat yang ricuh akibat lahan dan rumah yang tergusur jika semua itu ditinjau dari dimensi dasar manusia dan pendapat para filsof tentang manusia yang berasal dari tanah dan akan kembali lagi ke tanah.

\section{B. TEORI YANG DIGUNAKAN}


Teori yang digunakan untuk menganalisis masalah dan fenomena itu antara lain yaitu pandangan para filsof tentang anggapan bawha manusia berasal dari tanah dan akan kembali lagi ke tanah serta dimensi dasar manusia tentang sosialitas yang di dalamnya adanya makna aku dan yang lain serta dua posisi ekstrim dalam sosialitas yaitu individualisme dan kolektivisme

\section{PEMBAHASAN MASALAH DAN FENOMENA}

Kata "manusia" secara etimologis berasal dari Bahasa sansekerta : manusya. Dalam Bahasa Inggris Human, dari kata latin homo, yang berasal dari kata tanah (humus). Dari kata itu maka kita tidak boleh mengagungkan dan terlalu merendakan manusia. Indonesia merupakan negara yang beranekaragam mulai dari suku, agama, budaya serta adat di dalamnya, Indonesia merupakan negara yang unik. Salah satunya yang sering disoroti adalah adat dan budaya serta agama, manusia merupakan makluk ciptaan Tuhan yang diagungkan dan memiliki akal budi yang mampu diagungkan karena berbeda dengan makluk ciptaan Tuhan yang lain maka dari itu manusia memliki ha katas ciptaan Tuhan lainnya untuk dapat dijaga dan rawat dengan baik. Namun kita melihat di Indonesia banyak sekali penebangan liar serta pembunuhan liar terhadap hewan dan Tumbuhan, menurut teori filsafat dimensi dasar manusia yaitu sosialitas dikatakan aku dan yang lain aku adalah realitas. Yang lain juga relaitas. Makna dan hubungan yang terjadi jika manusia melampaui hubungan subjek - objek, yaitu masuk ke dalam hubungan intersubjektif. Intersubjektif adalah jalinan antar subjek yang terdiri di atas satu subjek transcendental. Subjek transcendental adalah kesatuan batiniah dari semua objek konkret (kemanusiaan). Pengalamanku bukanlah pengalaman yang lengkap. Pengalaman ini menjadi lengkap jika berhadapan dengan yang lain mengenal diri menjadi semakin sempurna jika berhadapan dengan yang lain. Yang lain dengan demikian adalah aku juga! Aku yang lain itu juga tampil secara penuh, dari teori ini aku berpendapat bahwa manusia belum merasa sempurna dan adanya nafsu duniawi, adanya nafsu yang harus terpenuhi secara terus menerus, mari kita melihat berapa banyak Hutan yang harus dikorban demi memenuhi nafsu manusia? Mari kita melihat berapa banyak hewan yang harus mati untuk memenuhi kebutuhan 
manusia, disini saya melihat bahwa manusia belum mengenal yang lain bahkan dirinya sendiri mengapa? Karena jika kita melihat hewan dan tumbuhan adalah makluk ciptaan Tuhan yang seharusnya kita jaga dan rawat, manusia memiliki akal budi yang seharusnya mampu memikirkan bahwa itu adalah ciptaan Tuhan namun terkadang kita tidak dapat memungkiri hal itu karena kebutuhan kita yang seakan tidak ada habisnya, namun apakah manusia sadar untuk mengembalikan apa yang telah diambil dari Alam, kita diberi kebebasan oleh Tuhan untuk memanfaatkan hewan danTumbuhan dengan bijak maka dari Itu jika kita membuhkan seharusnya dan sepastinya kita bertanggung jawab atas hal itu. Dengan ini manusia mampu memahami bahwa mereka hidup dengan yang lain yang seharusnya harus kita jaga dan kita lindungi, mari kita ambil contoh lain pembunuhan? Bunuh diri? Pembunuhan di Indonesia merupakan suatu tindakaan yang dilarang dimata Hukum, mari kita lihat dari kacamata filsafat manusia dari segi sosialitas aku dan yang lain, menurut saya pembunuhan dilakukan kerana kurang pemahaman aku dan yang lain, pembunuhan terjadi karena nafsu sesaat dan rasa benci maupun dendam yang terjadi, pelaku merasa tersakiti atas korban karena mungkin tidak dipahami, hal ini berarti manusia belum memahami konsep aku dan yang lain untuk saling memahami antar sesama, manusia juga telah mengusir Tuhan karena merasa tindakan pembunuhan setimpal dengan apa yang dia rasakan.

Jika kita kembali pada konsep manusia menurut para filsof bahwa manusia berasal dari tanah dan akan kembali lagi ke tanah, mari kita renungkan kejadiaan dan fenomena diatas apakah manusia dapat memahami bahwa dirinya akan kembali lagi di tanah? Saya pernah mendengar dan mencermati pepatah Tua "Urip iku mung mampir ngombe" jika saya memaknai pepatah itu, kata - kata itu sangat besar maknanya bagi saya, "Ngombe Banyu Putih" atau minum air putih merupakan tindakan yang sangat menyegarkan seluruh jiwa saya bahkan batin saya, jika kita memaknai hal itu hidup memang untuk mencari penyegaran secara batin dan jiwa maksudnya hidup itu harus terarah kepada sang pencipta dan sesama, manusia tidak hidup sendiri banyak sekali yang hidup diantara kita termasuk hewan dan Tumbuhan hal sekecil itu pun juga mampu menyegarkan karena kita menghargai apa yang ada di bumi ini dan menghargai ciptaan Tuhan maka hidup kita akan 
semakin terarah tidak hanya secara jiwa namun secara batin kita menjadi terpenuhi dan semakin memahami bahwa kita ini berharga di Mata Tuhan namun kita terkadang serakah terhadap apa yang ada disekitar kita, konsep manusia yang berasal dari tanah dan akan kembali lagi ke tanah serta hidup untuk memuliakan Tuhan dan sesame belum diresapi dengan baik. Mari kita melihat adat Indonesia dan Agamanya yang begitu unik menuruku, jika kita melihat dan menyandingkan tentang konsep manusia berasal dari Tanah dan akan kembali lagi ke tanah mari kita berpikir bagaiman ya dengan sistem penguburan jenasah jika kita melihat dari sudut pandang agama bahkan rasa tau suku?

Di Indonesia jika saya melihat ada dua tempat penguburan jenazah yang satu adalah jenazah para umum dan satu adanya tempat jenazah yang sangat mewah atau yang sering kita lihat adalah kuburan cina saya melihat disana hanya orang berkelas yang mampu mendirikan kuburan semewah itu, bukannya saya ingin mengkritik, mengapa harus semewah itu mengapa harus ada barang berharga yang mereka bawa ke dalam tanah apa ya bedanya jika semua kuburan itu disamakan saja? Bukankah manusia berasal dari tanah dan akan kembali lagi ke tanah? Bukankah semua nya akan bertemu dengan sang kuasa dengan kesederhanaan? Bukankah hal itu juga merupakan tindakan yang membeda - bedakan suku dan kasta? Mungkin saya kurang setuju karena mengapa kuburan harus dipisahkan? Namun kita tidak boleh berpikiran apatis semua itu terkadang ada maksud tersendiri dan bahkan untuk kebaikan. Ya itulah Indonesia dengan segala keunikan dan adat istiadat yang menyatukan, jika kita mampu memahami sesama maka kita akan bisa memahami siapa kita sebenarnya tanpa harus membeda - bedakan. Manusia adalah makluk yang memiliki akal budi yang mampu diselaraskan untuk memahami sesama. Indonesia juga merupakan negara dengan segudang adat yang berbeda beda terutama jika kita melihat bagaimana adat di toraja dengan prosesi pemakaman jenazah disana, disana pemakaman jenazah merupakan suatu adat istiadat yang sangat sacral, bahkan sebuah kelarga yang ditinggalkan harus mengorban kerbau dengan jumlah ratusan dan tidak boleh ditangisi karena mereka beranggapan keluarga yang meninggal akan kembalil lagi ke sang pencipta, namun terkadang adat disana juga tidak masuk akal juga menghabiskan banyak harta dan kekayaan 
untuk orang yang telah wafat, jika kita berpikiran bahwa manusia berasal dari tanah dan akan kembali lagi ke tanah mengapa harus semewah itu? Lalu jika melihat proses penguburan jenazah yang diperilakukan berdasarkan kasta dan berapa jumlah pengorbanan yang dikorbankan akan diberikan singgahsana atau tempat istimewa untuk jenazah tersebut. Ya begitulah Indonesia dengan segudang adat yang menarik perhatian, tapi semua itu memiliki maksud tersendiri, jika kita manusia yang memahami sesama pasti kita akan menghargai adat istiadat disetiap daerah. Karena kita tidak dapat hidup sendiri, banyak manusia yang ada disekitar kita. Hidup tidak hanya bermuluk pada sang kuasa tapi juga bagaiman kita memperilakukan ciptaan Tuhan terhadap sesama kita. Mari kita juga melihat dinamika dilingkungan sekitar kita jika kita melihat kembali dari kacamata dimensi dasar manusia tentang sosialitas yang didalamnya memiliki makna sosialitas adalah kebersamaan antar individu, sosialitas menjadi cara menunjukkan kehidupan bersama mari kita lihat dari sudut pandang dua posisi ekstrim dalam sosialitas serta aku dan yang lain. Di Indonesia sangat genjar dengan pembangunan untuk meningkatkan perekonomian di Indonesia salah satu pembangunan yang akan kita soroti adalah bandara NYIA di Yogjakarta tepatnya di kulon progo, bandara ini dibangun untuk menambah sector udara terutama trasnpotasi jalur udara agar menjadi lebig efisien mempermudah jalur udara dan menambah sector perekonomian disekitar wilayah Indonesia untuk pengiriman barang - barang yang terpencil agar dapat tersampaikan dengan baik, namun proses pembangunan bandara ini mendapat pertentangan dari berbagai pihak masyarakat kulon progo yang rumah dan sawahnya harus tergerus oleh pembangunan bandara itu, maka banyak para aktivis yang peduli dan tanggap akan hal itu dengan membantu masyrakat kulon progo menolak jika harus digusur dan dipindahkan lahannya, dan disinalah muncul konflik yang tidak ada habisnya sampai sekang, yaitu kekerasan antara para aktivis dan aparat yang menertibkan jalannya pembangunan disana, serta banyaknya aksi pembelaan terhadapat masyarakat yang dilakukan oleh aktivis. Disini kita melihat bahwa kekerasan terkadang mampu merendamkan amarah walaupun hanya sesaat tapi apakah masalah yang dihadapi akan dapat selesai dengan begitu saja, jika kita melihat dari kacamata sosialitas sikap manusia 
tidak dapat terkontrol kembali hanya ingin menang sendiri walupun dari segi masyarakat maupun apparat keamanan sikap aku dan yang lain tidak dapat disampaikan dengan baik oleh masing - masing pihak maka yang terjadi adalah kekerasan dan saling tuduh menuduh sampai harus berkorban habis - habisan untuk memperjuangkan tanah dan lahan serta lahan karena lahan dan rumah yang merasa berharga bagi mereka, tapi mari kita lihat jika kita mampu berpikir dengan sosialitas bahwa sosialitas adalah kebersamaan individu, sosialitas menjadi cara menunjukkan kehidupan bersama, pembangunan bandara jika saya melihat dari segi teknik industri pembangunan tersebut tidak semata - mata untuk menyenangkan atau menuntungkan satu pihak saja namun semua pihak dapat merasakan adanya bandara tersebut, bandahara tersebut dibangunan untuk kepentingan bangsa dan negara, mengurangi kegiatan impor barang terus menerus padahal kita mempunyai barang tersebut karena kita tidak mampu mengirimkan barang tersebut dikarenakan faktor transpotasi udara yang tidak memenuhi, dengan dibarengi itu maka pemerintah membangun bandara di kulon progo untuk lebih memperkuat sector perekonomian dan industry dengan ini diharapkan masyarakat mampu menikmati pembangunan ini dengan adanya bandara sector pengiriman BBM ke papua jadi lebih mudah dan masyarakat papua tidak merasa dibedakan untuk harga BBM di Jawa Dan Papua dengan adanya bandara asset di NTT yang mempunyai sapi kualitas sama denga Australia mampu dimanfaatkan dan mengurangi impor dari negara lain. Pembangunan terkadang dipandang sebelah mata oleh beberapa pihak karena banyaknya pengorbanan yang harus dikorban didalam sebuah pembangunan tersebut.

Terkadang pembangunan juga menjadi momok bagi masyarakat karena merasa kehilangan Sesuatu yang berharga yang dimiliki seperti tanah, lahan dan sebagianya. Jika saya melihat pembangunan bandara di kulon progo merupakan tindakan pemerintah yang sangat tepat, namun mengapa harus terjadi kekerasan dan tindak kejahatan yang menjadi jalan antara apparat keamanan dan para aktivis yang membela masyarakat? Terkadang saya juga merasa salut terhadap para aktivis karena mau berkorban untuk membela para masyarakat di kulon progo, namun terkadang juga saya merasa bimbang terhadap mereka apakah mereka tidak dapat 
bicara baik - baik terhadap pemerintah untuk menyelesaikan masalah tersebut? Jika jalur komunika menjadi jalur pertama yang dipilih dan sikap pemerintah yang legowo dan siap menerima segala masukan mungkin tindak kejahatan tidak akan terjadi, karena jika kita melihat dari sudut pandang kacamata dimensi dasar manusia Aku dan yang lain maka disitu akan tercipta pemahaman satu dengan yang lain untuk mencapai tujuan bersama, dan jika kita melihat dari kacamata sosialitas kolektivisme kebersamaan (keseluruhan) ada lebih dulu dan bersifat absolut pendasaran ontologisnya realitas social tidak berdasarkan dari individu. Realitas social memiliki raelitas adanya sendiri. Kepentingan bersama lebih penting dari kepentingan pribadi. Pembangunan harus berdasarkan untuk kepentingan bersama jika memang bendara di kulon progo untuk kepentingan masyarakat Indonesia, pemerintah juga harus memperhatikan masyarakat yang ada disana, mereka akan kehilangan tanah, rumah serta segala kenangan semasa disana, maka tindakan apa yang seharusnya dilakukan jika memang itu untuk sesame jangan sampai merugikan dan menjadi dampak kekerasan di sekitar masyarkat di kulon progo, mungkin jalan keluar yang harus ditempuh agar tidak adanya perlawanan antara lain jika memang itu untuk sesame dan paham bahwa kehidupan social kita antara aku dan yang lain maka derajat masyarakat kulon progo juga harus diperhatikan dengan baik, semacam sebulum bandara dibanguan masyarakat sudah diberikan tunjangan yang layak dan pengertian akan dibangunnya bandara di daerah tersebut. Dengan adanya itu mampu menjadikak bahwa pembangunan bukan lagi momok bagi masyarakat untuk takut, karena pembangunan merupakan kesejahteraan untuk sesama kita. 


\section{DAF TAR PUSTAKA}

Dewantara, Agustinus. "Filsafat Moral (Pergumulan Etis Keseharian Hidup Manusia)." (2017). 